\title{
NOTES FROM PRACTICE/UIT DIE PRAKTYK
}

\section{ADOPTION: A STORY OF TELLING AND OF HEALING}

I am an adoptive mother, and being a mother is one of the central aspects of my identity ... I am not sure if there is a difference in identity between biological mother and adoptive mother, for I have not been a biological mother. What I do know is that my daughter and I share a bond and a love that would stand the test of time of any parent-child relationship. I have an equal faith that she is as unconditionally loved by her father, Paul, who risked breaking conventional stereotypes about masculinity in the way he cared for her - from clinic visits, changing diapers, bathing, dressing and feeding and carrying her on his back, and swaying her to sleep especially when the ugly pains of colic brought on uncontrollable crying. He was the constant in her life whenever my work required travelling. Yet it was a love that would be marred by fear as she grew up. If he could, he would have denied the biological parents out of existence - not out of vindictiveness, but for the sheer pain of loving in fear ... and if it were left entirely up to him, he would have chosen not to tell at all.

There were a number of professional and personal encounters that influenced the decision I made in telling our daughter about being adopted, and these have shaped our relationship in powerful ways. I am an adoptive mother ... I am also a social worker, having worked in psychiatry and now as an academic - a senior professor in an institution that I was once not allowed to study in because of my race. My profession has been a double-edged sword providing me with the spaces to work through my own issues, and with knowledge and skills to deal with threatening and sensitive issues. On the down side, Paul often expressed the following view: "Thank God you are there to deal with it; I can't." He admitted to fear, on account of which he distanced himself from the telling and other difficult issues around the adoption, which left me feeling alone and unsupported. As I write, I wonder if my strength was the weakness - both mine and his.

I have run several adoption workshops and groups. One in particular stands out for me. I was invited by a student - who as part of her field practice education in a child welfare setting organised a workshop on telling in adoption - to facilitate the workshop. There were several parents there: mainly couples, a few mothers on their own and one lone father, whose wife was unable to attend. The participants were at varying points in their "telling" stories. Only two had informed and were comfortable about it. The overarching theme was the fear of telling and the emotional trauma that it engendered. The main fear was that if the child knew the truth, he or she would later leave the adoptive home in search of the biological parents. Another was that the truth would hurt the child. The most poignant response came from the lone father, who remained silent for the most part and after all the others had spoken said: "When she was six we thought she was too little and now that she is sixteen we think it is too late." In one sentence he so aptly captured the ambivalence of telling and the dilemmas involved in not knowing how to tell and when to tell. In prior research interviews that I conducted with parents who were planning to adopt most of them said that they would tell "when the child was old enough", and when I asked them what "old enough" was, their suggestions ranged from 14 to 21 years of age.

At that time Preshanthi, our daughter whom we had adopted at birth, was just over a year old. My heart reached out to this father and the other participants, for I too was going through similar ambivalence and pain. I more than just toyed with the idea of not telling. I seriously considered not telling as an option, even though, intellectually, I knew that it was not an option. 
I had worked with adolescents and adults who expressed such an extreme sense of betrayal on learning about being adopted late in life, usually under hostile circumstances. Yet for the first time, soon after her arrival into our lives, I considered the option of emigration. If we were in a strange country where we had no history, no neighbours and no immediate family, perhaps we would succeed in never telling the truth. It produced acute pain in me that my daughter, on knowing the truth, would have to confront an existential reality: At the moment of birth, my birthmother chose to give me up. I knew that this would be her existential burden to carry which might be accentuated during adolescence, no matter how much I framed the adoption as an act of love.

I entertained these thoughts even though we had an open adoption. The birthmother, Sohana, ${ }^{1}$ knew us; she was involved in selecting the baby's first items of clothing, in the choice of her name and she lived in our home just before and after the birth of Preshanthi. Sohana had intermittent contact with our daughter until she was about four years old, when we mutually agreed that she would phase out the visits. I spoke to my colleagues about my dilemmas and the fear of telling. I felt my daughter's innocence and love, and felt that telling would be like putting a knife through her; and I simply did not know how to go about telling. One of my colleagues recommended that I talk to her even as she was asleep. So I began when she was preverbal and at the beginning while she was asleep - telling her that she was adopted and deeply, deeply loved by her mummy and daddy. As she was growing up I told her stories of surrogate caring - the "once upon a time" stories with animals and chicks that over time evolved into telling about a mother who loved her baby so dearly but, who on account of being too young and not having a daddy for the baby, could not keep the baby. Because she loved the baby, she wanted the baby to stay with someone who could really take care of her and love her. To my surprise when she was about five years old she responded with: "Mummy isn't you talking about me, I am adopted" to which I simply said "yes"; this was followed by other even more surprising responses. Her questions revolved around the wellbeing of the birthmother did she have a home; did she have food; did she have a mummy and daddy? My heart swelled with pride that she would, at that age, think beyond herself. I was pleased that I could address her concerns with honesty - Sohana was a school teacher; she did have parents; she lived in a comfortable home and drove her own car.

Preshanthi began accompanying me to some adoption workshops while she was still very young, where she would hear adoptive parents and adopted children speak. Her Grade One teacher reported the following incident. After one such workshop, Preshanthi went up to her the following morning and asked how to spell "adopted". The teacher's response was: "Oh why are you thinking of adopting Zodwa?" [Zodwa was my daughter's classmate living in a children's home that we often served as host family for]. The teacher said that with an absolute sense of pride Preshanthi responded with: "No, it is because I am adopted." I was delighted that she was growing up with a positive sense of self. While Sohana's visits stopped, Preshanthi and I talked openly about adoption. When Preshanthi was about eight years old, we bumped into Sohana. I informed her that Sohana was the birthmother; three of us had coffee together and talked - a conversation that was quite spontaneous and easy, with Preshanthi addressing me as mummy and Sohana as auntie, the same pattern as when Preshanthi was much younger.

1 Not her real name 
The openness that I shared with Preshanthi about the adoption and the relationship with the birthmother often caused disquiet among some of my friends and family. Their biggest concern was that Preshanthi would leave us when she grew up. My response always was: "All that I can do is to love her unconditionally in the present; the future will take care of itself". I regretted not being able to provide answers to her questions about the biological father (Sohana was never willing to share anything about him) and I thought that this was a huge missing link in her life. With the onset of early adolescence, Preshanthi preferred not to talk about adoption openly and she once told me so. Much later I learnt that a cousin told her that adoption was not a good thing and that she should not talk about it with her friends.

As anticipated, Preshanthi did experience her existential crises when she reached adolescence. Adolescents, in their search for self and identity, test the boundaries in their relationships with adults, especially parents. Preshanthi's behaviour was more than mere adolescent testing the limits; I sensed an inner turmoil that she was unwilling or unable to articulate. One morning when she was sixteen years old I got into bed with her and tried to create a safe space for her to talk. I held her in my arms as she cried - not being able to articulate why she was crying. At one point I verbalised for her what I thought might be going on in her head. I said: "It must be so difficult for you when you feel abandoned and alone, yet knowing that you are the centre of mummy's and daddy's life and that we love you so much. Do you think this might have anything to do with being adopted?" This is when the floodgates opened. She cried so bitterly and uncontrollably. How does an adolescent reconcile knowing being loved and cared for and yet feeling alone and abandoned? How does she articulate the feelings of abandonment to adoptive parents without hurting them? How does she come to terms with the guilt attached to these feelings? (They are good parents so I should not be feeling this way). I told her that I had anticipated that this would happen, and normalised it by letting her know that I would have been surprised if it did not happen and that, although her feelings might seem eminently irrational, they were real.

I shared with her my own sense of abandonment by my father (who committed suicide when I was five months old) and how it took me a long, long time to separate my sense of self from that of my father and to accept that his choice had nothing to do with me. I told her that was my burden to carry, the shadows of which still lurk sometimes. We all have demons and burdens to carry; I told her that I would certainly carry hers if I could, but that it was hers to carry and that I knew that she had the strength to carry it and to work through issues. I asked if she wanted me to re-establish contact with Sohana; she said yes. I called the office and cancelled my appointments. We went out to breakfast and a movie and had a wonderful day out. At the end of the day, Preshanthi said: "Mummy, thank you for the lovely day."

I immediately set about the task of calling Sohana to let her know that Preshanthi would like to meet her. It was a difficult time and Sohana could not do this; she would call when she was ready. The call came ... one year later. The night before Preshanthi"s meeting with Sohana, I went into Preshanthi's room and said: "You know, even though I am organising this, I am anxious." Her immediate response was: "Me too, but why are you anxious?" Before my response came the reassurance: "But one thing for sure is that I will not leave the only parents that I know and the only home that I know to go and live with $\mathrm{S} * * * * *$ "

In November 2008 I received a call from Sohana saying that the biological father wanted to see Preshanthi. Preshanthi was busy with final examinations, 2nd year law at University, so I suggested that we wait two weeks before informing her, indicating that the decision to meet would have to be hers. My anger about the biological father surfacing after 19 years was 
indescribable! What right did he have to claim any space in her life after not playing any role in her growing up? Paul was equally angry, but perhaps more than anger was the fear of being displaced and of loss. He wanted nothing to do with the meeting. The difference between me and Paul was that I was willing to move beyond my fear and anger in order to respond to Preshanthi's birthright to know her identity. On 9 December 2008 we met and Preshanthi and her biological father were then left alone to talk, later joined by Sohana. I rejoined after a couple of hours and the four of us ended up having lunch together. I am not sure what Paul's exclusion of himself from all of this has done to him. I can only imagine that it reinforces fear, 2 which can be such an overpowering human emotion. I hoped that the meeting with the biological father would help to round the circle and provide some closure for Preshanthi ... but who knows, it might be the beginning of yet another chapter in her life!

* Not her real name

Prof Vishanthie Sewpaul, School of Social Work and Community Development, University of KwaZulu-Natal, Howard College Campus, Durban, South Africa.

\footnotetext{
${ }^{2}$ Paul, Preshanthi and Sohana support the contents of this article. It is hoped that by sharing the struggles and pain about telling, we would be able to help other parents who are undergoing similar experiences.
} 